\title{
Implementasi Metode Pembelajaran Inkuiri dalam Meningkatkan Hasil Pembelajaran Mata Pelajaran PAI
}

\author{
Muhammad Heriyudanta \\ IAIN Ponorogo \\ yudanta10@gmail.com
}

\begin{abstract}
Abstrak
Para pakar pendidikan dan hasil penelitian menyebutkan bahwa, hingga saat ini masih banyak ditemukan peserta didik kita yang dalam belajar cenderung hanya mempelajari materi dengan cara menghafal materi secara normatif saja. Karena itu, perlu diimplementasikan metode-metode yang dapat merangsang daya nalar peserta didik, supaya nalar mereka dapat berfungsi secara baik. Penelitian ini bertujuan untuk mengetahui bagaimana implementasi metode pembelajaran inkuiri dalam meningkatkan hasil pembelajaran pada mata pelajaran PAI. Jenis penelitian ini merupakan penelitian lapangan (field research) dengan pendekatan kualitatif. Metode pengumpulan data dalam penelitian ini adalah wawancara, observasi, dan dokumentasi. Sumber data primer penelitian ini adalah kepala sekolah, guru PAI dan sejumlah peserta didik. Sedangkan sumber skundernya adalah data-data dari hasil observasi dan dokumentasi penelitian, seperti yang telah menjadi buku, jurnal, majalah, dan lainnya. Dari hasil penelitian, ditemukan bahwa model pembelajaran dengan menggunakan metode inkuiri dapat menjadikan siswa lebih aktif, kreatif, inovatif, mandiri, kritis, dan percaya diri untuk menjadi dirinya sendiri. Para siswa secara umum menjadi lebih percaya diri dalam bernalar, menganalisis, dan mengungkapkan pendapatnya dalam rangka untuk memecahkan masalah-masalah yang ada.
\end{abstract}

Kata Kunci: Metode Pembelajaran Inkuiri, Hasil Pembelajaran, PAI

\begin{abstract}
Education experts and research results state that, until now, there are still many of our students who in learning tend to only learn the material by memorizing the material normatively. Therefore, it is necessary to implement methods that can stimulate the reasoning power of students, so that their reasoning can function properly. This study aims to determine how the implementation of the inquiry learning method in improving learning outcomes in PAI subjects at SDN Bogorejo, Kec. Source, Kab. Rembang. This type of research is a field research with a qualitative approach. Data collection methods in this study were interviews, observation, and documentation. The primary data sources for this study were the principal, PAI teachers and a number of students. While the secondary sources are data from observations and research documentation, such as those that have become books, journals, magazines, and others. From the results of the study, it was found that the learning model using this inquiry method can actually make students more active, creative, innovative, independent, critical, and confident to be themselves. Students generally become more confident in reasoning, analyzing, and expressing their opinions to solve existing problems
\end{abstract}

Keywords: Inquiry Learning Methods, Learning Outcomes, PAI 


\section{A. PENDAHULUAN}

Tidak hanya pakar pendidikan, berbagai kalangan kini telah berani mendefinisikan istilah pendidikan secara bermacam-macam yang sebenarnya banyak dipengaruhi oleh pandangan dunia (weltanschauung) masing-masing. Kendati demikian, sesungguhnya semua pandangan yang berbeda itu dapat bertemu pada satu titik. Sebab, perbedaan tersebut hanya pada tataran redaksional semata, bukan berbeda secara substansional. Secara proses, pendidikan lebih berarti daripada sekedar pengajaran. Pengajaran dapat dikatakan sebagai suatu upaya dan proses transformasi ilmu pengetahuan dan kecakapan saja, tanpa disertai transformasi nilai dan pembentukan kepribadian dengan segala aspek yang dicakupnya. Sehingga, pengajaran lebih berorientasi pada pembentukan para "tukangtukang", para ahli (expert) atau para spesialis yang terpenjara dalam ruang spesialisasinya yang sempit. ${ }^{1}$

Sementara pendidikan, selain melakukan pengajaran juga sekaligus ada upaya serius untuk mentransfer nilai, yang bertujuan untuk menggodok emosi dan spiritual peserta didik. Dengan kata lain, perbedaan pendidikan dengan pengajaran terletak pada titik tekan pendidikan yang berusaha membentuk kesadaran dan kepribadian anak didik di samping transfer ilmu dan keahlian. Dengan proses pendidikan itu sebuah negara bisa mewariskan berbagai nilai-nilai luhurnya, nilai-nilai keagamaannya, ideologi-ideologinya, gagasangagasannya, kebudayaan-kebudayaannya generasi penerusnya, supaya dapat menjalani dan mengisi kehidupan di masa mendatang secara baik, efektif, dan efesien. Tokoh pendidikan nasional Indonesia, Ki Hajar Dewantara menyatakan; pendidikan pada umumnya berarti daya upaya untuk memajukan budi pekerti (kekuatan batin), pikiran (intelek), dan jasmani anak-anak, selaras dengan alam dan masyarakatnya. ${ }^{2}$ Secara lebih filosofis Muhammad Natsir dalam tulisan "Idiologi Didikan Islam", yang disebut pendidikan adalah suatu pimpinan jasmani dan rohani menuju kesempurnaan dan kelengkapan arti kemanusiaan dengan arti sesungguhnya. ${ }^{3}$ Yakni, pendidikan merupakan suatu proses kegiatan penyiapan generasi muda agar mampu menapaki kehidupannya secara efektif dan efisien sehingga berujung pada kesejahteraan hidup.

Pendidikan supaya dapat terselenggara dengan baik dan dapat mencapai tujuan-tujuan yang diharapkan, harus dikelola secara serius dan professional. Berbagai komponen pendidikan mulai dari guru, kurikulum, sarana prasarana, lingkungan pendidikan dan seterusnya harus berfungsi secara prima dan satu sama lain tidak boleh pincang. Guru harus memiliki kualifikasi kompetensi yang unggul, kurikulum harus relevan dengan situasi, kondisi, dan zaman, sarana prasarana harus lengkap dan memadai, lingkungan pendidikan pun juga harus mendukung dan kondusif.

Salah satu hal penting yang sama sekali tidak boleh luput dari perhatian guru dalam mendidik anak didiknya adalah metodenya. Dalam mendidik, guru tidak boleh asal-asalan

${ }^{1}$ Azyumardi Azra, Pendidikan Islam: Tradisi Dan Modernisasi Di Tengah Tantangan Milenium III (Jakarta: Kencana, 2002), hlm. 4.

2 Ki Hajar Dewantara, Masalah Kebudayaan; Kenang-Kenangan Promosi Doktor Honoris Causa (Yogyakarta: Pustaka Pelajar, 1967), hlm. 42.

${ }^{3}$ Moh. Natsir, Kapita Selekta (Bandung: Gravenhage, 1954), hlm. 87. 
dalam memilih dan menggunakan metode. Metode yang digunakan harus dipertimbangkan dengan materi yang sedang diajarkan, dengan kebutuhan siswa, dengan kondisi dan perhatian siswa, dan seterusnya. Beberapa tahun terahir juga bermunculan berbagai macam jenis metode pendidikan yang diciptakan oleh para pakar pendidikan, demi lebih tercapainya tujuan-tujuan yang dicita-citakan. Lahirnya 101 metode aktif learning misalnya menjadi bukti bahwa betapa pentingnya metode di tengah aktifitas penyelenggaraan pendidikan. ${ }^{4}$ Dari sini sehingga tidak mengherankan jika terdapat pandangan yang tidak asing lagi di telinga kita, yang menyatakan bahwa, "metode pendidikan lebih penting daripada materi pendidikan".

Pemilihan metode yang tepat dalam pembelajaran sangat memiliki pengaruh bagi pencapaian tujuan yang telah direncanakan. Secara umum, metode pendidikan dapat diartikan sebagai cara yang dapat digunakan untuk mempermudah dalam mencapai tujuan pendidikan. Banyak metode pembelajaran yang dapat diimplementasikan oleh guru dalam sebuah aktifitas pembelajaran. Namun, semua metode pembelajaran dan pendidikan yang ada tersebut, tidak untuk diimplementasikan semuanya secara bersama-sama dalam setiap pembelajaran. Karena itu, guru harus mempertimbangkan dan menentukan pilihan tentang metode apa yang paling sesuai untuk pembeajaran yang sedang dilakukan. Prinsip dasar yang tidak boleh ditinggalkan dalam memilih metode adalah yang penting metode yang diaplikasikan dapat merasa nyaman dan gembira di tengah proses pendidikan yang sedang dilakukan.

Salah satu metode yang dapat diaplikasikan guru dalam mengajar adalah metode Inkuiri. Metode inkuiri dapat diartikan sebagai sebuah metode pembelajaran di mana dalam pembelajaran tersebut ditekankan supaya siswa dapar berpikir secara kritis, analitis, dan kreatif, untuk menemukenali pertanyaan yang dimunculkan secara mandiri, serta menemukan jawaban sendiri dari pertanyaan-pertanyaan yang diajukan. ${ }^{5}$ Metode inkuiri menekankan pada permasalahan bagaimana siswa menggunakan sumber belajar. ${ }^{6}$ Dimana sumber belajar ini dipakai untuk mengidentifikasi masalah dan merumuskan masalah. Metode inkuiri dapat dikatakan tergolong sebagai salah satu metode yang relatif baru yang pernah ditawarkan oleh para pakar pendidikan. Metode inkuiri dipandang relevan hingga detik ini, lantaran fungsinya yang benar-benar dapat memantik kreatifitas peserta didik dalam kegiatan berpikir dan menalar. Dengan metode inkuiri ini siswa diharapkan dapat memiliki paradigm berpikir yang filosofis sehingga di kemudian hari siswa memiliki bekal untuk mengurai dan menjawab berbagai problematika hidup yang ada.

Menurut guru-guru di sana, dalam pembelajaran semua mata pelajaran yang ada, termasuk mata pelajaran PAI di SDN Bogorejo Kec. Sumber Kab. Rembang, ditemukan kasus bahwa peserta didik dalam belajar cenderung hanya mempelajari materi dengan

\footnotetext{
${ }^{4}$ Lihat Mel Silberman, Active Learning: 101 Strategi Pembelajaran Aktif (Yogyakarta: Pustaka Insan Madani, 2006).

${ }^{5}$ Wina Sanjaya, Strategi Pembelajaran Berorientasi Standar Proses Pendidikan (Jakarta: Kencana, 2008), hlm. 194.

6 Aninomus, Karakteristik Peserta Didik, Strategi dan Metode Pembelajaran, http://www.t125.co.cc/2010/karakteristik-peserta-didik-strategi-htm, diakses tanggal 2 Februari
} 
pendekatan hafalan materi secara normatif saja. ${ }^{7}$ Karena itu, kemampuan berpikir dan menalar para siswa bisa dibilang kurang dapat bekerja dengan baik. Padahal sesungguhnya, ilmu agama Islam adalah sebuah ilmu yang sangat lekat dengan yang namanya kegiatan berpikir dan menalar. ${ }^{8}$ Karena itu, untuk memperkenalkan sebuah pembelajaran yang aktif, kreatif, melatih nalar, dan menyenangkan, guru mengimplementasikan sebuah metode yang disebut dengan metode inkuiri. Harapannya adalah melalui metode inkuiri ini, pembelajaran ilmu agama Islam tidak hanya melakukan hafalan secara normatif saja, namun selain hafalan siswa juga diperkenalkan untuk melakukan kegiatan berpikir dan menalar secara baik terhadap berbagai macam problematika ilmu agama Islam.

Penelitian ini memiliki fokus untuk, pertama, mengetahui dan memahami definisi metode inkuiri. Kedua, mengetahui bagaimana implementasi, serta faktor-faktor penghambat dan pendukung dalam mengimplementasikan metode pembelajaran inkuiri untuk meningkatkan hasil pembelajaran pada mata pelajaran PAI di SDN Bogorejo, Kec. Sumber, Kab. Rembang. Terahir, untuk mengetahui bagaimana hasil implementasi metode pembelajaran inkuiri dalam meningkatkan hasil pembelajaran pada mata pelajaran PAI di SDN Bogorejo, Kec. Sumber, Kab. Rembang.

\section{B. METODE PENELITIAN}

Jenis penelitian ini merupakan penelitian lapangan ( field research) dengan pendekatan kualitatif, dimana penelitian ini berupaya mendeskripsikan tentang implementasi metode pembelajaran inkuiri dalam meningkatkan hasil pembelajaran peserta didik pada mata pelajaran PAI di SDN Bogorejo, Kec. Sumber, Kab. Rembang. Penelitian kualitatif adalah sebuah metode penelitian yang memakai latar alamiah, dengan tujuan menginterpretasikan fenomena yang terjadi dan dilakukan dengan cara melibatkan berbagai metode yang ada. Metode pengumpulan data yang biasanya digunakan dalam penelitian kualitatif ini adalah wawancara, observasi, dan dokumentasi. ${ }^{9}$ Sumber data primer penelitian ini adalah: 1. kepala sekolah; 2. guru PAI 3. sejumlah peserta didik. Sedangkan sumber skundernya adalah data-data dari hasil observasi dan dokumentasi penelitian, seperti yang telah menjadi buku, jurnal, majalah, dan lainnya.

\section{HASIL DAN PEMBAHASAN}

\section{Pengertian Metode Inkuiri}

Metode Inkuiri merupakan metode pembelajaran yang memberikan penekanan khusus pada proses menalar secara kritis dan analitis untuk mencari dan menemukan jawaban sendiri atas pertanyaan yang ada. ${ }^{10}$ Dari sini dapat dikatakan bahwa metode inkuiri merupakan metode pembelajaran yang menekankan pada pengembangan nalar kritis dan analitis peserta didik. Peserta didik dilatih untuk menggunakan nalarnya secara serius

\footnotetext{
7 Parini, “Urgensi Metode Inkuiri Dalam Dunia Pendidikan,” Lingkar Jateng, 2021.

${ }^{8}$ Miftah Ahmad Fathoni, Pengantar Studi Islam (Pendekatan Islam Dalam Memahami Agama) (Semarang: Gunungjati Semarang, 2001), hlm. 59.

${ }^{9}$ Lexy Moleong, Metodologi Penelitian Kualitatif (Bandung: PT Remaja Rosda Karya, 2000), hlm. 5.

10 Sanjaya, Strategi Pembelajaran Berorientasi Standar Proses Pendidikan, hlm. 194.
} 
supaya dapat terlatih dalam memecahkan semua problem yang muncul dan mungkin muncul. Istilah Inkuiri ini diambil dari istilah bahasa Inggris inquiry yang memiliki arti proses bertanya sekaligus mencari tahu atas jawaban dari pertanyaan ilmiah yang dimunculkan. ${ }^{11}$ Tujuan metode Inkuiri dalam pembelajaran adalah melatih peserta didik supaya memiliki kedisiplinan yang tinggi dan mencoba untuk menggali serta melatih keterampilan intelektual (intellectual skill) siswa dengan cara merangsang rasa ingin tahu (curiosity) siswa, kemudian berdasarkan rasa ingin tahunya tersebut, siswa diminta untuk mengajukan pertanyaan sekaligus mencari dan menemukan jawabannya sendiri. ${ }^{12}$ Inkuiri masuk dalam kategori model pengolahan informasi, di mana model pembelajaran ini lebih menekankan pada sejumlah aktivitas yang terkait dengan kegiatan proses atau pengolahan informasi untuk meningkatkan kapabilitas siswa melalui proses pembelajaran. ${ }^{13}$

Metode inkuiri dapat juga dikatakan sebagai metode yang menyiapkan siswa untuk bereksperimen secara mandiri dan seluas-luasnya supaya dapat mengetahui apa yang diamat. Metode inkuiri mengajarkan siswa untuk mau melakukan sesuatu, mengajarkan siswa untuk membangun kreatifitas berpikir dalam bertanya secara kritis, sekaligus mengajarkan siswa supaya mau berusaha keras menjawab secara mandiri berbagai pertanyaan-pertanyaan yang juga dimunculkan sendiri. Selain itu, metode inkuiri juga melatih siswa untuk berdialog dalam menghubungkan dan membandingkan hasil temuantemuan jawaban dari teman-temannya atau peserta didik lain. ${ }^{14}$

Dari beberapa penjelasan di atas maka dapat disimpulkan dan ditegaskan bahwa metode inkuiri bertujuan dan berguna antara lain untuk; 1. Menggali, mengembangkan, dan mengasah ketrampilan intelektual peserta didik supaya memiliki kemampuan berpikir kritis, analitis, dan kontemplatif. 2. Mengajari dan melatih peserta didik untuk memiliki kemampuan dalam menentukan pilihan serta memutuskan sesuatu secara mandiri dan objektif; 3. Melatih siswa untuk memiliki rasa ingin tahu yang tinggi, melatih siswa untuk memiliki percaya diri yang tinggi, serta melatih siswa untuk dapat mandiri dan dapat bekerja sama dengan orang lain. ${ }^{15}$

Dengan metode inkuiri ini memang membuka peluang atas lahirnya peserta didik yang memiliki rasa ingin tahu yang tinggi, dapat berpikir secara kritis-analitis, dan dapat memecahkan masalah secara mandiri. Namun, untuk mensukseskannya peran guru yang kompeten sangat diperlukan. Beberapa peranan guru yang harus ditunaikan dalam menjalankan metode inkuiri ini adalah sebagai motivator, fasilitator, penanya, administrator, pengaruh manager, dan sebagai rewarder (pemberi penghargaan). ${ }^{16}$ Karena dalam implementasi metode inkuiri ini guru bukan sebagai subjek sentral pembelajaran,

11 Muslimin Ibrahim, Pembelajaran Inkuiri, http://herfis.blogspot.com/2009/07/pembelajaraninkuiri.html, hlm., 1.

12 Aunurrahman, Belajar Dan Pembelajaran (Bandung: Alfabeta, 2013), hlm. 161.

${ }^{13}$ Aunurrahman, hlm. 157.

14 E. Mulyasa, Menjadi Guru Profesional: Menciptakan Pembelajaran Kreatif Dan Menyenangkan ((Bandung: PT Remaja Rosdakarya, 2005), hlm. 108.

${ }^{15}$ Niken Indraswati, "Peningkaan Kemampuan Siswa Dalam Menentukan Pokok Pikiran Bacaan Melalui Metode Inkuir," Jurnal Pendidikan, 2011.

${ }^{16}$ N. K Roestiyah, Strategi Belajar Mengajar (Jakarta: Rineka Cipta, 2008), hlm. 77. 
maka penekanan utamanya terletak pada: ${ }^{17} 1$. Siswa harus terlibat secara serius dan optimal dalam proses pembelajaran. 2. Kegiatan pembelajaran harus benar-benar diarahkan secara terencana, sistematis, dan terukur untuk mencapai tujuan pembelajaran.

\section{Implementasi Metode Inkuiri pada Mata Pelajaran PAI di SDN Bogorejo, Kec. Sumber, Kab. Rembang serta Faktor-faktor Pendukung dan Penghambatnya.}

Latar belakang dari diterapkannya metode inkuiri pada mata pelajaran PAI di SDN Bogorejo, Kec. Sumber, Kab. Rembang adalah karena kondisi pembelajaran PAI di sana dapat dikatakan monoton dengan hanya menggunakan metode ceramah dan hafalan saja yang dominan. Akibatnya, siswa menjadi bosan dalam belajar sehingga berimplikasi pada pemahaman materi atau prestasi belajar siswa yang kurang maksimal. Karakteristik pembelajaran di sana hampir sama seperti konsep pembelajaran yang disebut oleh Paulo Freire dengan istilah pendidikan gaya bank. ${ }^{18}$

Pendidikan gaya bank adalah sebuah model pendidikan di mana guru menjadi figur kebenaran tunggal yang memandang siswa atau peserta didik sebagai botol kosong yang harus diisi atau dijejali dengan informasi-informasi baru atau ilmu-ilmu baru. Sistem pendidikan semacam ini suasana kelas dikendalikan oleh guru (Teacher center) sementara peserta didik harus selalu mengikuti arahan-arahan guru. Barangkali dapat dikatakan sistem pendidikan tersebut memiliki gaya di mana guru menjelaskan siswa mendengarkan, guru memerintah siswa mengikuti, guru mengisi siswa diisi, guru menganalisi siswa menerima analisisnya, guru tidak masuk kelas siswa tidak belajar, dan seterusnya. ${ }^{19}$

Sistem pendidikan semacam ini di satu sisi memang memberikan pendidikan kepada siswa mengenai budi pekerti atau tata krama kepada guru. Guru dalam konteks ini memperoleh penghormatan setinggi-tingginya dari semua siswa. Namun di sisi lain, ternyata sistem pendidikan gaya bank memberikan implikasi negatif yang cukup besar, yakni terbunuhnya daya kreatifitas, inovasi, dan nalar peserta didik secara masal. Dengan kata lain sistem pendidikan gaya bank tersebut membungkam siswa sekaligus memasung kebebasan siswa sebagai manusia. Bahkan tidak berlebihan kiranya jika dikatakan pembunuhan terhadap hak asasi manusia (HAM) para siswa itu sendiri. Sebab idealnya, ketika guru menjelaskan, menganalisis, dan menemukan teori, seharusnya peserta didik juga melakukan hal yang sama. Sehingga dengan seperti itu maka daya nalar, kreatifitas, dan inovasi peserta didik akan hidup dan berkembang yang pada gilirannya peserta didik dapat menjadi dirinya sendiri, dapat mengenali dirinya sendiri, dan dapat mengeksploitasi segala potensi yang ada dalam dirinya.

17 Trianto, Model-Model Pembelajaran Inovatif Berorientasi Konstruktivistik (Jakarta: Prestasi Pustaka, 2011), hlm. 135.

18 Anatri Desstya et al., "MODEL PENDIDIKAN PAULO FREIRE, REFLEKSI PENDIDIKAN IPA SD DI INDONESIA (Relevansi Model Pendidikan Paulo Freire Dengan Pendidikan IPA Di Sekolah Dasar)," Profesi Pendidikan Dasar 1, no. 1 (2018): 1, https://doi.org/10.23917/ppd.v1i1.2745.

${ }^{19}$ Abdul Rasyid, "Pendidikan Humanis Dalam Pandangan Paulo Freire," Ekspose: Jurnal Penelitian Hukum Dan Pendidikan 17, no. 1 (2019): 514, https://doi.org/10.30863/ekspose.v17i1.109. 
Bertolak dari alasan tersebut, kemudian guru PAI SDN Bogorejo, Kec. Sumber, Kab. Rembang mengimplementasikan metode inkuiri pada mata pelajaran PAI dengan harapan dan tujuan untuk meningkatkan hasil belajar siswa. Tekniknya dengan cara guru memberikan salah satu materi PAI yang ada, kemudian diajarkan dengan menggunakan metode inkuiri. Misalnya guru memberikan materi tentang puasa. Kemudian para siswa diwajibkan untuk mengeksploitasi informas-informasi secara mendalam dan serius mengenai konsep puasa tersebut. Dalam hal ini tentu siswa harus mengakses berbagai sumber informasi baik itu dari media cetak ataupun elektronik sebanyak-banyaknya. Intinya murid diberikan kebebasan untuk memperoleh ilmu pengetahuan seluas-luasnya dari materi yang sedang dipelajari dengan menggunakan media apa saja. Harapan dan tujuan metode inkuiri ini adalah supaya siswa dapat berkreasi, berinovasi, dan bebas menggunakan nalarnya sehingga mereka tidak terkungkung dan tidak berani mengungkapkan opininya dengan percaya diri.

Karena itu pembelajaran dengan menggunakan metode inkuiri ini membutuhkan kemandirian siswa, motivasi siswa, semangat siswa, dan rasa ingin tahu (curiosity) siswa yang tinggi. ${ }^{20}$ Pada titik ini kemudian siswa-siswa SDN Bogorejo menghadapi berbagai problematika. Misalnya, siswa kurang memiliki akses informasi yang baik, motivasi dan semangat siswa dalam belajar mandiri kurang baik, siswa justru kurang mampu untuk memperoleh informasi materi ketimbang ketika tidak menggunakan metode inkuiri. Namun demikian, banyak pihak juga mendukung untuk diimplementasikannya metode inkuiri ini dalam penyelenggaraan pendidikan di SDN Bogorejo ini. Beberapa alasannya misalnya, melatih siswa untuk memiliki semangat belajar, merangsang siswa supaya memiliki rasa ingin tahu yang tinggi, melatih siswa supaya mandiri, melatih siswa supaya mau bekerja kelompok dengan temannya dalam belajar, melatih siswa supaya menggunakan nalarnya, dan lain sebagainya. Dengan kata lain, mereka diharapkan dapat menjadi pribadi-pribadi yang memiliki semangat tinggi, memiliki rasa ingin tahu tinggi, memiliki jiwa kemandirian dan menjadi pejuang yang tangguh, serta mau bernalar sehingga tumbuh kreatifitas dan inovasi yang maksimal.

\section{Hasil Belajar Mata Pelajaran PAI dengan Menggunakan Metode Inkuiri di SDN Bogorejo, Kec. Sumber, Kab. Rembang.}

Dari hasil penelitian, ditemukan bahwa model pembelajaran dengan menggunakan metode inkuiri ini benar-benar dapat menjadikan siswa lebih aktif, kreatif, inovatif, mandiri, kritis, dan percaya diri untuk menjadi dirinya sendiri. Para siswa secara umum menjadi lebih percaya diri dalam bernalar, menganalisis, dan mengungkapkan pendapatnya. Walaupun memang pada awalnya metode inkuiri ini menyulitkan siswa dalam memahami materi PAI yang diajarkan guru lantaran mereka harus mencari informasi sendiri mengenai materi yang diajarkan. Namun seiring dengan berjalannya waktu, para siswa kemudian terbiasa dan

20 Dwi Nugraheni Rositawati, "KAJIAN BERPIKIR KRITIS PADA METODE INKUIRI," Prosiding SNFA (Seminar Nasional Fisika Dan Aplikasinya) 3 (2019): 74, https://doi.org/10.20961/prosidingsnfa.v3i0.28514. 
justru menjadi pribadi-pribadi yang lebih tangguh dalam belajar, menggali informasi, menganalisis, dan mengungkapkan pandangan-pandangannya.

Melihat hasil tersebut, menurut peneliti, metode inkuiri memang sangat cocok untuk diterapkan di era seperti sekarang ini di mana akses informasi sangat mudah diperoleh di manapun dan kapanpun. Siswa dengan menggunakan smart phonenya dapat berselancar ke seluruh penjuru dunia dengan murah dan praktis. Dunia seolah berada dalam genggaman, dan informasi apa saja dapat diperoleh dengan cepat dan akurat. Namun jika metode inkuiri diterapkan untuk siswa SD, menurut hemat peneliti guru tidak boleh lepas begitu saja dalam melakukan pengawalan pembelajaran. Dalam konteks ini guru harus membiarkan siswa untuk bereksplorasi menggunakan nalar dan kreatifitasnya, namun pada saat yang sama guru juga harus mengawal secara ketat, supaya siswa yang masih anak-anak itu dapat dipastikan memperoleh informasi yang benar, bernalar yang benar, sekaligus benar-benar dapat memahami materi yang sedang dipelajari. Sementara ketika metode inkuiri ini diimplementasikan pada siswa menengah atas ataupun bahkan mahasiswa, menurut peneliti guru atau dosen dapat memberikan kelonggaran bagi siswa yang lebih maksimal supaya siswa atau mahasiswa tidak terkungkung dalam sudut pandang yang sempit serta dapat menjadi pribadi yang matang. Namun walaupun demikian, guru atau dosen juga tetap harus melakukan bimbingan dan arahan secara serius kepada peserta didik dan mahasiswa.

Namun jika terdapat kasus para siswa atau mahasiswa yang sulit untuk belajar secara mandiri, maka di sini guru atau dosen harus bekerja keras membangunkan motivasi peserta didik, memberikan stimulus, memberikan hukuman, dan seterusnya. Sesungguhnya motivasi siswa dalam belajar dapat dikatakan menjadi penentu dari keberhasilan implementasi metode inkuiri ini. Sehingga jika guru atau dosen menginginkan metode inkuiri ini berhasil, maka tenaga pendidik harus benar-benar membangun budaya dan motivasi belajar yang tinggi di tengah-tengah peserta didik. ${ }^{21}$

\section{PENUTUP}

\section{Simpulan}

Metode inkuiri dapat diartikan sebagai sebuah metode pembelajaran di mana dalam pembelajaran tersebut ditekankan supaya siswa dapar berpikir secara kritis, analitis, dan kreatif, untuk menemukenali pertanyaan yang dimunculkan secara mandiri, serta menemukan jawaban sendiri dari pertanyaan-pertanyaan yang diajukan. Teknik implementasi metode inkuiri di sini dengan cara guru memberikan salah satu materi PAI yang ada, kemudian diajarkan dengan menggunakan metode inkuiri. Misalnya guru memberikan materi tentang puasa. Kemudian para siswa diwajibkan untuk mengeksploitasi informas-informasi secara mendalam dan serius mengenai konsep puasa tersebut. Dari hasil penelitian, ditemukan bahwa model pembelajaran dengan menggunakan metode inkuiri ini benar-benar dapat menjadikan siswa lebih aktif, kreatif, inovatif, mandiri, kritis, dan percaya

${ }^{21}$ Saliman, “PENDEKATAN INKUIRI DALAM PEMBELAJARAN,” INFORMASI 2, no. XXXV (2009). 
diri untuk menjadi dirinya sendiri. Para siswa secara umum menjadi lebih percaya diri dalam bernalar, menganalisis, dan mengungkapkan pendapatnya.

\section{Saran}

Merujuk pada temuan penelitian di atas, peneliti menyarankan kepada semua guru untuk mencoba dan mengimplementasikan metode inkuiri dalam melakukan proses pembelajaran di ruang-ruang kelas. Dengan menggunakan metode inkuiri ini, diharapkan peserta didik akan memiliki daya kreatifitas menalar yang lebih baik.

\section{E. DAFTAR PUSTAKA}

Aunurrahman. Belajar Dan Pembelajaran. Bandung: Alfabeta, 2013.

Azra, Azyumardi. Pendidikan Islam: Tradisi Dan Modernisasi Di Tengah Tantangan Milenium

III. Jakarta: Kencana, 2002.

Desstya, Anatri, Istiani Indah Novitasari, Aldi Farhan Razak, and Kukuh Sandy Sudrajat.

"Model Pendidikan Paulo Freire, Refleksi Pendidikan Ipa Sd Di Indonesia (Relevansi

Model Pendidikan Paulo Freire Dengan Pendidikan IPA Di Sekolah Dasar)." Profesi

Pendidikan Dasar 1, no. 1 (2018): 1. https://doi.org/10.23917/ppd.v1i1.2745.

Dewantara, Ki Hajar. Masalah Kebudayaan; Kenang-Kenangan Promosi Doktor Honoris Causa.

Yogyakarta: Pustaka Pelajar, 1967.

Fathoni, Miftah Ahmad. Pengantar Studi Islam (Pendekatan Islam Dalam Memahami Agama).

Semarang: Gunungjati Semarang, 2001.

Indraswati, Niken. "Peningkaan Kemampuan Siswa Dalam Menentukan Pokok Pikiran Bacaan Melalui Metode Inkuir." Jurnal Pendidikan, 2011.

Moleong, Lexy. Metodologi Penelitian Kualitatif. Bandung: PT Remaja Rosda Karya, 2000.

Mulyasa, E. Menjadi Guru Profesional: Menciptakan Pembelajaran Kreatif Dan Menyenangkan.

(Bandung: PT Remaja Rosdakarya, 2005.

Natsir, Moh. Kapita Selekta. Bandung: Gravenhage, 1954.

Parini. “Urgensi Metode Inkuiri Dalam Dunia Pendidikan.” Lingkar Jateng. 2021.

Rasyid, Abdul. "Pendidikan Humanis Dalam Pandangan Paulo Freire." Ekspose: Jurnal

Penelitian Hukum Dan Pendidikan 17, no. 1 (2019): 514.

https://doi.org/10.30863/ekspose.v17i1.109.

Roestiyah, N. K. Strategi Belajar Mengajar. Jakarta: Rineka Cipta, 2008.

Rositawati, Dwi Nugraheni. "Kajian Berpikir Kritis Pada Metode Inkuiri." Prosiding SNFA

(Seminar Nasional Fisika Dan Aplikasinya) 3 (2019): 74. https://doi.org/10.20961/prosidingsnfa.v3i0.28514.

Saliman. "PENDEKATAN INKUIRI DALAM PEMBELAJARAN." INFORMASI 2, no. XXXV (2009).

Sanjaya, Wina. Strategi Pembelajaran Berorientasi Standar Proses Pendidikan. Jakarta: Kencana, 2008.

Silberman, Mel. Active Learning: 101 Strategi Pembelajaran Aktif. Yogyakarta: Pustaka Insan Madani, 2006. 
Implementasi Metode Pembelajaran | 83

Trianto. Model-Model Pembelajaran Inovatif Berorientasi Konstruktivistik. Jakarta: Prestasi Pustaka, 2011. 